\title{
Los poderes de los Tribunales Administrativos de Recursos Contractuales en la Ley de Contratos del Sector Público de 2017***
}

Martín María Razquin Lizarraga

DOI: https://doi.org/10.47623/ivap-rvap.110.2018.1.06

\begin{abstract}
Sumario: I. Las exigencias de las Directivas europeas de recursos en materia de contratación pública.-II. La posición española en la transposición de las Directivas de recursos. - III. La situación previa a la LCSP.-IV. La regulación de los TARC en la LCSP: 1. Los TARC. 2. Los poderes de los TARC. 2.1. Su competencia. 2.2. Los actos impugnables. 2.3. El examen de legalidad. 2.4. Las decisiones que pueden adoptar: contenido de las resoluciones. 2.4.1. Medidas cautelares. 2.4.2. Indemnización. 2.4.3. Anulación: ¿carácter simplemente revisor? 2.4.4. Sanciones versus condena en costas. 2.4.5. Otras cuestiones resueltas por la LCSP. 2.5. La ejecución de sus resoluciones. - V. Conclusiones. - VI. Bibliografía.
\end{abstract}

\section{Las exigencias de las Directivas europeas de recursos en materia de contratación pública}

La Directiva 89/665/CEE, de 21 de diciembre de 1989, reguló, por vez primera, la exigencia a los Estados miembros de adoptar un sistema

* Las abreviaturas utilizadas son las siguientes:

- LCSP: Ley 9/2017, de 8 de noviembre, de Contratos del Sector Público.

- LCSP/2007: Ley 30/2007, de 30 de octubre, de Contratos del Sector Público.

- LJCA: Ley 29/1998, de 13 de julio, reguladora de la jurisdicción contencioso-administrativa.

- LPAC: Ley 39/2015, de 1 de octubre, del Procedimiento Administrativo Común de las Administraciones Públicas.

- LRJPAC: Ley 30/1992, de 26 de noviembre, de Régimen Jurídico de las Administraciones Públicas y del Procedimiento Administrativo Común.

- TACR: Tribunales Administrativos de Recursos Contractuales.

- TACRC: Tribunal Administrativo Central de Recursos Contractuales.

- TJUE: Tribunal de Justicia de la Unión Europea.

- TRLCSP: Texto Refundido de la Ley de Contratos del Sector Público, aprobado por Real Decreto Legislativo $3 / 2011$, de 14 de noviembre.

* El presente trabajo constituye una versión reelaborada más extensa de mi colaboración al Libro Homenaje dedicado al Profesor Luciano Parejo Alfonso, de la Universidad Carlos III de Madrid, con motivo de su jubilación tras una larga y fructífera carrera académica, en la que he tenido la suerte de coincidir en varias ocasiones. 
de recursos ágiles y eficaces para combatir las vulneraciones de las Directivas materiales sobre contratos públicos de obras y de suministros, que después se extendió también a los contratos de servicios(1). Y más tarde la Directiva 92/13/CEE, de 25 de febrero de 1992 adoptó similares (no exactamente iguales) disposiciones para los contratos de los sectores del agua, la energía, los transportes y las telecomunicaciones (2).

Los objetivos de estas Directivas pueden resumirse del siguiente modo:

- Garantizar la aplicación efectiva de las Directivas materiales sobre contratación pública.

- Arbitrar medios de recurso eficaces y rápidos.

- Ofrecer la obtención de medidas provisionales.

- Dar un tratamiento urgente a estos procedimientos de recurso para solventar las infracciones de las Directivas.

Para ello estas Directivas obligan a que se otorguen unos determinados poderes a los órganos resolutorios de los recursos en materia de contratación pública (art. 2.1 Directiva 89/665/CEE):

-Adopción de medidas provisionales.

- Anulación de decisiones ilegales.

- Concesión de indemnización por daños y perjuicios.

Conviene resaltar que la Directiva 89/665/CEE contenía la siguiente previsión respecto del supuesto en que la resolución de estos recursos en materia de contratación pública se encomendara a órganos no jurisdiccionales (3):

"Cuando los organismos responsables de los procedimientos de recurso no sean de carácter jurisdiccional, sus decisiones deberán ir siempre motivadas por escrito. Además, en ese caso, deberán adoptarse disposiciones para que cualquier medida presuntamente ilegal adoptada

(1) GIMENO FELIÚ ha explicado el fundamento europeo del control de la contratación pública que ha constituido una auténtica revolución jurídica y el avance sobre el modelo inicial efectuado por el TJUE (Sistema de Control de la Contratación Pública en España, Ed. Thomson Reuters Aranzadi, Cizur Menor (Navarra), 2016, págs. 23-30).

(2) Debe advertirse que el presente trabajo se centrará en la Directiva 89/665/CEE y sus modificaciones, así como en su adaptación por la LCSP.

(3) LÓPEZ MENUDO insiste en las previsiones de la Directiva sobre órganos jurisdiccionales o no jurisdiccionales, eso sí independientes, colegiados y a cuyos miembros debe exigírseles una cualificación profesional («Transposición irregular de la normativa europea sobre el Tribunal de recursos contractuales: ¿Un modelo para la resolución de los recursos administrativos en general?", en la obra colectiva Derecho administrativo e integración europea: estudios en homenaje al profesor José Luis Martínez López-Muñiz, tomo 2, Ed. Reus, Madrid, 2017, págs. 1411-1434). 
por el organismo de base competente o cualquier presunta infracción cometida en el ejercicio de los poderes que tiene conferidos, pueda ser objeto de un recurso jurisdiccional o de un recurso ante otro organismo que sea una jurisdicción en el sentido del artículo 177 del Tratado y que sea independiente en relación con el poder adjudicador y con el organismo de base.

El nombramiento de los miembros de este organismo independiente y la terminación de su mandato estarán sujetos a las mismas condiciones aplicables a los jueces en lo relativo a la autoridad responsable de su nombramiento, la duración de su mandato y su revocabilidad. Como mínimo, el presidente de este organismo independiente deberá poseer las mismas cualificaciones jurídicas y profesionales que un juez. Dicho organismo independiente adoptará sus decisiones previa realización de un procedimiento contradictorio y tales decisiones tendrán, por los medios que estipule cada Estado miembro, efectos jurídicos vinculantes» (art. 2.8).

La Directiva 2007/66/CE modificó de forma importante las anteriores Directivas, introduciendo importantes novedades respecto de la llamada «ineficacia», el plazo suspensión, la suspensión automática cuando la decisión recurrida sea la de adjudicación y los plazos de recurso.

Así, en caso de ineficacia además pueden imponer multas al poder adjudicador y también reducir la duración del contrato (art. 2 sexies apartado 2) como sanciones alternativas a las consecuencias derivadas de la ineficacia del contrato conforme a la legislación nacional (art. 2 quinques apartado 2).

Sin embargo, en lo que aquí interesa (los poderes de los TARC) las modificaciones han sido muy pocas, puesto que los apartados 1 y 8 de la Directiva 89/665/CEE han sufrido muy pequeñas alteraciones, ninguna relevante. El apartado 1, tras la modificación de 2007 sigue teniendo prácticamente la misma redacción. $Y$ el apartado 8 ha pasado a ser ahora el apartado 9, con la pequeña modificación de la referencia al precepto correspondiente del nuevo Tratado de la Comunidad Europea.

La Directiva 2014/23/UE ha ampliado el ámbito de los recursos a las concesiones, pero no ha efectuado ninguna modificación en el art. 2 de la Directiva 89/665/CEE.

Esto quiere decir que el sistema arbitrado por las Directivas de recursos desde el año 1989 permanece prácticamente inalterado en lo que se refiere a los poderes de los órganos que deben resolver estos recursos, y en especial si dichos órganos no van a ser jurisdiccionales.

Sí que han cambiado las normas sobre los recursos especiales, principalmente en cuanto al ámbito de los contratos sujetos a ellos, como respecto de los plazos y la suspensión. 


\section{La posición española en la transposición de las Directivas de recursos}

La posición inicial española (4) fue la de no transponer las Directivas de recursos, por entender que se trataba de una cuestión que ya tenía solución en el ordenamiento jurídico español. Así se defendió que las previsiones de la LRJPAC cumplían satisfactoriamente con las exigencias de las Directivas de recursos.

Y con motivo de la adaptación a España de las Directivas de tercera generación de 2004, mediante las Leyes 30 y 31/2007, de 30 de octubre, no se introdujo ninguna novedad legislativa en lo referente al sistema de resolución de recursos. Ello suponía mantener los recursos ordinarios, de alzada y potestativo de reposición, de la LRJPAC y posteriormente el recurso contencioso-administrativo regulado en la LJCA.

Sin embargo, esta posición no fue aceptada por la Comisión Europea que presentó un recurso por incumplimiento contra España. Resultado de dicho recurso, es la Sentencia del TJUE de 3 de abril de 2008, asunto C-444/06), por la que se estimó parcialmente el recurso y se condenó a España por incumplimiento en la transposición de la Directiva de recursos puesto que el ordenamiento jurídico español no respondía a todas las exigencias de la Directiva 89/665/CEE.

Ello motivó que España aprobara la Ley 34/2010, de 5 de agosto, con la finalidad de dar cumplimiento a las exigencias de las Directivas de recursos. La Ley 34/2010 añadió a la LCSP/2007 un nuevo Libro VI (arts. 310-320) bajo el título de "Régimen especial de revisión de decisiones en materia de contratación y medios alternativos de resolución de conflictos" (5).

Como se ha indicado, las Directivas se limitan a exigir la creación de un sistema de recursos ágiles y eficaces, pero sin imponer que los mismos deban ser resueltos por un órgano jurisdiccional. Más bien, del art. 2.9 (tras la reforma de 2007) de la Directiva 89/665/CEE se desprende la aceptación de un órgano no jurisdiccional.

Pues bien, España optó por no encomendar el conocimiento de este sistema de recursos en materia contractual a los Juzgados y Tribunales de lo contencioso-administrativo, y procedió a crear unos órganos administrativos especializados denominados Tribunales Administrativos de Re-

(4) Sobre la posición inicial española hasta la Ley 34/2010, véase SANTAMARÍA PASTOR, J.A., Los recursos especiales en materia de contratos del sector público, Ed. Aranzadi, Cizur Menor (Navarra), 2015, págs. 33-40

(5) Una explicación de esta reforma legal puede verse en RAZOUIN LIZARRAGA, J.A., «EI sistema especial de recursos en la contratación pública tras la reforma de la Ley de Contratos del Sector Público", en Revista General de Derecho Administrativo núm. 25/2010. 
cursos Contractuales (6). Conviene recordar que la exposición de motivos de la Ley 34/2010 no contiene una explicación de por qué se ha optado por la creación de estos Tribunales Administrativos. Más bien se trata de una exposición de motivos que oculta la verdadera razón de su creación, que anuda únicamente a la Directiva 2007/66/CE como si la LCSP/2007 hubiera dado ya cumplimiento a la Directiva 89/665/CEE. Para ello basta reparar en dos apartados significativos de esta exposición de motivos:

"En aplicación de estos principios, a la hora de incorporar el contenido de la Directiva a las Leyes 30/2007, de 30 de octubre, de Contratos del Sector Público y 31/2007, de 30 de octubre, sobre Procedimientos de Contratación en los sectores del agua, la energía, los transportes y los servicios postales, es fundamental establecer un procedimiento de trámites ágiles en que la decisión resolutoria pueda adoptarse en el tiempo más breve posible sin dejar de atender a la garantía de los derechos de los interesados.

Ambas Leyes contienen ya normas reguladoras de los recursos o reclamaciones, según los casos, que pueden interponerse contra los actos de adjudicación o contra los actos del procedimiento administrativo que les sirve de base. E incluso ambas prevén el plazo de suspensión subsiguiente a la adjudicación, la suspensión del acto como consecuencia de la interposición del recurso o reclamación y la adopción de medidas cautelares. Quedan, sin embargo, por resolver algunas cuestiones tales como la relativa a la competencia para la resolución del recurso que la nueva Directiva exige se atribuya a un órgano independiente o a la suspensión de la adjudicación que debe mantenerse hasta que dicho órgano resuelva sobre el mantenimiento o no de ella o sobre el fondo".

En definitiva, de su lectura poco se desprende sobre tan trascendental decisión como es la creación de estos TARC, dejando de lado la vía de los recursos ordinarios, y creando por tanto un recurso especial, cuando menos para los contratos sujetos a regulación armonizada.

Sin embargo, en el fondo late la ineficacia del sistema tradicional del recurso contencioso-administrativo (7) y el retraso de los jueces y tribunales de esta jurisdicción, así como también de otros mecanismos de

(6) GIMENO FELIÚ explica la opción española por el recurso administrativo especial y las características de este recurso más cercanas a un recurso contencioso-administrativo que a un recurso administrativo, con el que no es compatible (Sistema de Control de la Contratación Pública en España Ed.Thomson Reuters-Aranzadi, Cizur Menor (Navarra), 2016, págs. 30-41).

(7) RAZQUIN LIZARRAGA, M.M. ha resaltado que la creación de Tribunales y Consejos Administrativos sobre recursos y reclamaciones obedece al fracaso de la jurisdicción contencioso-administrativa para dar respuesta adecuada a los mismos ("Los Tribunales y Consejos Administrativos sobre recursos y reclamaciones", en PAREJO ALFONSO, L. y VIDA FERNÁNDEZ, J. (Coord.), Los retos del Estado y la Administración en el siglo XXI. Libro Homenaje al profesor Tomás de la Quadra-Salcedo Fernández del Castillo, ed. Tirant lo Blanch, Valencia 2017, t. I, págs. 549-571, págs. 549-553). 
control en el ámbito administrativo, tanto de los recursos administrativos (8), como el control interno particularmente de la contratación pública (9).

Con ello se consagra un doble sistema de recursos en función de que el contrato esté o no sujeto a regulación armonizada:

1) Para los contratos sujetos a regulación armonizada, existe la posibilidad de acudir a la vía del recurso especial ante los nuevos TARC, aunque con carácter potestativo, porque puede acudirse directamente a la vía judicial (10).

2) Para los contratos no sujetos a regulación armonizada, sigue vigente el sistema tradicional de recursos previstos en la LRJPAC (de alzada y de reposición) y posteriormente el recurso contenciosoadministrativo.

Por otra parte, este sistema alcanza también a los contratos sujetos a regulación armonizada de los poderes adjudicadores que no sean Administraciones Públicas, con lo cual para éstos se produce una sustancial diferencia, puesto que por el contrario sus contratos no sujetos a regulación armonizada quedan fuera del ámbito del Derecho Administrativo.

Asimismo, se extiende a los contratos subvencionados que estén sujetos a regulación armonizada.

(8) Así lo apuntan LÓPEZ MENUDO («Transposición irregular de la normativa europea sobre el Tribunal de recursos contractuales: ¿Un modelo para la resolución de los recursos administrativos en general?", op. cit., págs. 1411-1412) y los diversos trabajos contenidos en la obra colectiva dirigida por LÓPEZ RAMÓN, F., Las vías administrativas a debate, Ed. INAP, 2016, donde se recogen las Actas del XI Congreso de Profesores de Derecho Administrativo celebrado en Zaragoza en febrero de 2016. Conviene resaltar el resumen de la relatora del Congreso, MOREU CARBONELL, E., "Valoración del sistema español de recursos administrativos: conclusiones», págs. 827-838.

(9) Véase en este sentido el trabajo de DOMINGUEZ MARTíN, M., "El sistema de justicia administrativa y la incidencia de los mecanismos administrativos de control en la jurisdicción contencioso-administrativa: reformas y necesidades", en AGUDO GONZÁLEZ, A., Control Administrativo y Justicia Administrativa, Ed. INAP, Madrid, 2016, págs. 81-101. En dicho trabajo es especialmente interesante el análisis del Informe sobre Justicia Administrativa 2015 del Centro de Investigación sobre Justicia Administrativo (CIJA-UAM), que muestra su lentitud, su conflictividad y además que en este orden jurisdiccional su duplican los niveles de pendencia respecto de otros órdenes jurisdiccionales. Y por ello se postula porque las vías alternativas de recurso (como aquí el recurso especial) constituyan medios de reducción de la litigiosidad a nivel jurisdiccional (págs. 81-101).

(10) MALARET GARCÍA, E. ha apuntado que se va hacia un modelo de justicia administrativa dual de Tribunales Administrativos y de jurisdicción contencioso-administrativa y afirma que la creación de los TARC ha sido necesaria para asegurar la efectividad de la justicia administrativa ( modelo de justicia administrativa dual. Tribunales administrativos y jurisdicción contencioso-administrativa. Justicia Administrativa. Instituciones Administrativas e instancias jurisdiccionales. Una perspectiva necesariamente de conjunto del control de la actividad administrativa", en AGUDO GONZÁLEZ, A., Control Administrativo y Justicia Administrativa, Ed. INAP, Madrid, 2016, págs. 7174). 
Este sistema se inserta más tarde en el Texto Refundido de la Ley de Contratos del Sector Público (Real Decreto Legislativo 3/2011, de 14 de noviembre, en adelante, TRLCSP), y fue objeto de desarrollo por el Real Decreto 814/2015, de 11 de septiembre.

En resumen, se trata de un recurso especial que sustituye a los recursos administrativos (art. 40.5TRLCSP), excepto en el caso de las Comunidades Autónomas donde éstas pueden mantenerlos (art. 41.3 TRLCSP), que tiene carácter potestativo (art. 40.6 TRLCSP) y que se configura como un recurso precontractual. Y se complementa con el recurso postcontractual que recibe el nombre de cuestión de nulidad (art. 37TRLCSP). Ambos son resueltos por los TARC.

Como explica SANTAMARÍA PASTOR(11), el modelo español es un sistema administrativo, que ha marginado la opción judicial, y ha optado por un sistema plural y territorializado de diversos TARC, donde es relevante el estatuto de sus miembros y la estructura y funciones de estos TARC.

El art. 41 TRLCSP regula estos TARC, disponiendo la posible existencia de tres tipos deTribunales Administrativos:

1) Tribunal Administrativo Central de Recursos Contractuales.

2) Tribunales Administrativos Autonómicos de Recursos Contractuales.

3) Tribunal Administrativos Locales de Recursos Contractuales, aunque su creación se deja en manos de las Comunidades Autónomas.

Sus poderes vienen limitados a los descritos en el art. 2.1 de la Directiva 89/665/CEE: anulación de actos impugnados, concesión de medidas provisionales, e imposición de la obligación de indemnización y en relación con los contratos de los poderes adjudicadores sujetos a regulación armonizada.

\section{La situación previa a la LCSP}

La situación previa a la LCSP, viene dada por la existencia de leyes autonómicas que ofrecen una regulación más abierta o amplia del recurso especial, puesto que crean TARC de ámbito autonómico que conocen no sólo de contratos sujetos a regulación armonizada, sino también de otros contratos inferiores al umbral comunitario, o de otros aspectos (modificados y encargos). Es el caso de la Ley Foral de Contratos Públicos de $\mathrm{Na}$ varra que permite el recurso especial contra todos los actos en materia de

(11) Los recursos especiales en materia de contratos del sector público, op. cit., págs. 45-64. 
contratos sin distinción entre contratos sujetos o no a regulación armonizada(12), o la Ley de Aragón sobre contratación pública que rebaja las cuantías establecidas, aunque no se trata de un recurso general(13).Y es, por ello, que el Consejo de Estado reiteró, en relación con el Anteproyecto, su recomendación de ampliar el recurso especial a todos los contratos públicos (Dictamen de 10 de marzo de 2016).

También se aprobó el Reglamento del recurso especial y del Tribunal Administrativo Central de Recursos Contractuales (en adelante, TACRC) mediante el Real Decreto 814/2015, de 11 de septiembre, con carácter básico y aplicable a todos los TARC (disposiciones final primera y adicional primera) (14).

Asimismo el Informe sobre la Justicia Administrativa 2015 elaborado por CIJA-UAM ratifica que la situación sigue siendo extremadamente débil, con un alto nivel de pendencia y una larga duración de los procesos(15). Ello provoca la posición doctrinal de seguir profundizando y ampliando la vía del recurso especial ante los TARC(16).

Por otra parte, la jurisprudencia del TJUE ratifica en diversas sentencias el alcance las Directivas de recursos. Así la STJUE de 26 de noviembre de 2015 (asunto C-166/14) confirma que la Directiva de recursos alcanza solamente a los contratos comprendidos en el ámbito de aplicación de la Directiva 2004/18.

Por otra parte, la STJUE de 6 de octubre de 2015 (asunto C-203/14) consideró que el TARC de Cataluña puede ser considerado un órgano judicial(17)

(12) Art. 210 de la Ley Foral 6/2006, de 9 de julio, de Contratos Públicos.

(13) Aragón ha ido reduciendo sus cuantía desde la Ley 3/2011, de 24 de febrero, modificada por la Ley 10/2012, de 27 de diciembre, y finalmente por la Ley 5/2017, de 1 de junio, quedando las cuantías en la actualidad en 200.000 euros para los contratos de obras y en 60.000 para los contratos de suministro y de servicios.

(14) Como más adelante se irá destacando, Ilama la atención que determinados preceptos de este Reglamento se hayan elevado a rango legal mediante su incorporación a la LCSP, mientras que otros a veces más relevantes siguen en la esfera reglamentaria.

(15) El Informe ofrece un estudio específico dedicado a la contratación pública y en sus conclusiones (págs. 215-216) apunta medidas de mejora de la jurisdicción contencioso-administrativa.

(16) Así lo explica VALCÁRCEL FERNÁNDEZ, P., quien se pregunta si hay motivos para el optimismo por el incremento de los recursos especiales, su rápida resolución y el bajo número de recursos contencioso-administrativos frente a las resoluciones de los TARC que son estimados («El recurso especial en materia de contratos públicos: en la senda del derecho a una buena administración", en la obra colectiva Las vías administrativas de recurso a debate. Actas del XI Congreso de la Asociación Española de Profesores de Derecho Administrativo. Zaragoza, 5 y 6 de febrero de 2016, Ed. INAP, Madrid, 2016, págs. 307-315).

(17) A pesar de ello, LÓPEZ MENUDO insiste en que estos Tribunales no se incardinan en el Poder Judicial y por tanto no son órganos jurisdiccionales a nivel interno y ni siquiera cuasi jurisdiccionales ( «Transposición irregular de la normativa europea sobre el Tribunal de recursos contractuales: ¿Un modelo para la resolución de los recursos administrativos en general?», op. cit., pág. 1414). 
a los efectos de plantear cuestiones prejudiciales conforme al art. 267 Tratado de Funcionamiento de la Unión Europea(18). En el examen del cumplimiento de los requisitos exigidos por este precepto, conviene ahora detenerse en las afirmaciones del TJUE sobre la independencia del TARC de Cataluña:

"19 A continuación, en cuanto al criterio de la independencia, se desprende de los autos en poder del Tribunal de Justicia que el Tribunal Català de Contractes del Sector Públic tiene la condición de tercero con respecto a la autoridad que adoptó la decisión recurrida en el litigio principal (véanse las sentencias Corbiau, C-24/92, EU:C:1993:118, apartado 15, y Wilson, C-506/04, EU:C:2006:587, apartado 49). En este contexto, es evidente que dicho Tribunal ejerce sus funciones con plena autonomía, sin estar sometido a vínculo jerárquico o de subordinación alguno respecto a terceros y sin recibir órdenes ni instrucciones de origen alguno (véase la sentencia Torresi, C-58/13 y C-59/13, EU:C:2014:2088, apartado 22), estando así protegido de injerencias o presiones externas que puedan hacer peligrar la independencia de juicio de sus miembros (sentencias Wilson, C-506/04, EU:C:2006:587, apartado 51, y TDC, C-222/13, EU:2014:2265, apartado 30).

20 Es pacífico, además, que dicho Tribunal ejerce sus funciones con total respeto de la objetividad y de la imparcialidad frente a las partes en litigio y a sus respectivos intereses en relación con el objeto del litigio. Por otra parte, con arreglo al artículo 8, apartado 4, del Decreto 221/2013 de la Generalidad de Cataluña, los miembros de ese órgano son inamovibles, y sólo pueden ser cesados por alguna de las causas expresamente enumeradas en esa disposición (véanse las sentencias Wilson, C-506/04, EU:C:2006:587, apartados 52 y 53, y TDC, C-222/13, EU:2014:2265, apartados 31 y 32).

Esta doctrina ha sido reiterada para la Comisión nacional de revisión de los procedimientos de adjudicación de contratos públicos de Eslovenia, considerada también órgano juris-

\footnotetext{
(18) Véase un comentario a esta STJUE en HERNÁNDEZ GONZÁLEZ, F. L., "Sobre la controvertida naturaleza "jurisdiccional" de los tribunales administrativos de recursos contractuales", en la obra colectiva Las vías administrativas de recurso a debate. Actas del XI Congreso de la Asociación Española de Profesores de Derecho Administrativo. Zaragoza, 5 y 6 de febrero de 2016, Ed. INAP, Madrid, págs. 499-510; y también en VALCÁRCEL FERNÁNDEZ, P., «El recurso especial en materia de contratos públicos: en la senda del derecho a una buena administración", op. cit., págs. 326-332.
} 
diccional en la STJUE de 8 de junio de 2017 (C-296/15, apartados 32-38)".

Por su parte, la STJUE de 5 de abril de 2016 (C-689/13) confirma la doctrina de la Sentencia de 4 de julio de 2013 (C-100/12), e insiste en la necesaria efectividad de la vía de recurso prevista en la Directiva 89/665 que no puede ser paralizada por la presentación de un recurso incidental (19).

La STJUE de 5 de abril de 2017 (asunto C-391/15) ha resuelto una cuestión prejudicial formulada por el Tribunal Superior de Justicia de Andalucía respecto de la interpretación de la Directiva 89/665/CEE en relación con el art. 310.2 de la LCSP/2007 en relación con la admisión de recurso especial contra los actos de trámite de un ente adjudicador, como puede ser la decisión de admisión a trámite de una oferta de un licitador respecto del que se denuncia el incumplimiento de las disposiciones sobre justificación de la solvencia técnica y económica previstas en las Directivas y en la normativa española sobre contratación pública, así como sobre si los arts. 1.1. y 2.1. a) y b) de la Directiva tienen efecto directo. La respuesta a ambas cuestiones es afirmativa: los actos de admisión son decisiones recurribles por la vía del recurso especial y los preceptos citados de la Directiva tienen efecto directo por ser incondicionales y suficientemente precisos.

(19) El fallo de la STJUE de 4 de julio de 2013 es el siguiente: «El artículo 1, apartado 3, de la Directiva 89/665/CEE del Consejo, de 21 de diciembre de 1989, relativa a la coordinación de las disposiciones legales, reglamentarias y administrativas referentes a la aplicación de los procedimientos de recurso en materia de adjudicación de los contratos públicos de suministros y de obras, en su versión modificada por la Directiva 2007/66/CE del Parlamento Europeo y del Consejo, de 11 de diciembre de 2007, debe interpretarse en el sentido de que, si en el marco de un procedimiento de recurso el adjudicatario que obtuvo el contrato y que ha interpuesto un recurso incidental plantea una excepción de inadmisibilidad basada en la falta de legitimación del licitador que interpuso aquel recurso debido a que la oferta presentada por éste debería haber sido rechazada por la entidad adjudicadora por no ajustarse a las especificaciones técnicas definidas en el pliego de condiciones, la citada disposición se opone a que se declare la inadmisibilidad de dicho recurso como consecuencia del examen previo de esa excepción de inadmisibilidad sin pronunciarse acerca de si cumplen las especificaciones técnicas tanto la oferta del adjudicatario que obtuvo el contrato como la del licitador que interpuso el recurso principal».

Y el fallo de la Sentencia de 5de abril de 2016 dice así en el apartado 1 que es el que aquí interesa: «El artículo 1, apartados 1, párrafo tercero, y 3, de la Directiva 89/665/CEE del Consejo, de 21 de diciembre de 1989, relativa a la coordinación de las disposiciones legales, reglamentarias y administrativas referentes a la aplicación de los procedimientos de recurso en materia de adjudicación de los contratos públicos de suministros y de obras, en su versión modificada por la Directiva 2007/66/ CE del Parlamento Europeo y del Consejo, de 11 de diciembre de 2007, debe interpretarse en el sentido de que se opone a que un recurso principal interpuesto por un licitador que tiene un interés en obtener un contrato determinado y que se ha visto o puede verse perjudicado por una supuesta vulneración del Derecho de la Unión en materia de contratos públicos o de las normas por las que se transpone dicho Derecho, y que tiene por objeto la exclusión de otro licitador, sea declarado inadmisible con arreglo a normas procesales nacionales que establecen el examen previo del recurso incidental interpuesto por ese otro licitador". 
Por otra parte el Informe de la Comisión Europea de 24 de enero de 2017 sobre la eficacia de las Directivas de recursos efectúa un resumen del contenido de éstas en los términos que siguen.

Por un lado, afirma que: "Las Directivas sobre procedimientos de recurso permiten que se presenten demandas tanto antes de que se haya firmado el contrato (recursos precontractuales) como después de su firma (recursos postcontractuales). Entre las vías de recurso precontractuales se incluyen el derecho a medidas provisionales, un plazo suspensivo obligatorio entre la decisión de adjudicación y la celebración del contrato y la obligación de suspender el procedimiento de concesión mientras se investiga el recurso para evitar la adjudicación del contrato. Las vías de recurso postcontractuales pretenden declarar sin efecto un contrato existente $u$ ofrecer compensación (principalmente daños y perjuicios) a las partes afectadas después de que se haya adjudicado el contrato en cuestión. Además, otros elementos fundamentales de las Directivas sobre procedimientos de recurso son la comunicación automática a los licitadores de las razones por las que no han resultado elegidos, el régimen de plazos para incoar procedimientos y las sanciones alternativas (a saber, la reducción de la duración del contrato o la imposición de multas) cuando la ineficacia o falta de efectos no resulte apropiada".

Esto es lo que han adoptado los Estados miembros: "En todos los Estados miembros existen, asimismo, disposiciones en relación con los tres tipos obligatorios de recursos (medidas provisionales, resoluciones de anulación y daños y perjuicios), pero su enfoque varía considerablemente dependiendo de sus tradiciones jurídicas".

Por lo que respecto a los órganos encargados de resolver estos recursos, el Informe da cuenta de los dos modelos de soluciones que han adoptado los Estados miembros: "Como consecuencia, en cada Estado miembro se han establecido diferentes órganos de recurso. En catorce Estados miembros (Bulgaria, Chipre, Chequia, Alemania, Dinamarca, Estonia, España, Croacia, Hungría, Malta, Polonia, Rumanía, Eslovenia y Eslovaquia) existe un órgano administrativo de recurso en materia de contratación pública, algunos especializados y otros no. En el resto de los Estados miembros, un órgano judicial de recurso ya existente es el responsable de la revisión de los procedimientos de contratación pública». No obstante, más adelante advierte que la intervención de los órganos no jurisdiccionales parece más eficaz: «Algunos sistemas nacionales exigen que sean los órganos administrativos de recurso y no los órganos jurisdiccionales ordinarios los encargados de la protección jurídica en primera instancia en relación con los procedimientos de contratación pública. Como tendencia general, estos tienden a ser más eficaces. Lo confirmaron una gran mayoría de encuestados en la consulta pública $(74,7 \%)$ al considerar que los procedimientos ante los órganos jurisdiccionales ordi- 
narios llevan, por lo general, más tiempo y dan lugar a criterios de adjudicación menos estrictos que los procedimientos ante órganos administrativos de recurso especializados".

$Y$ el Informe concluye que, aunque no se precisa una reforma urgente ni relevante de las Directivas de recursos, sí que existen aspectos de mejora entre los que se incluye el fomento de la cooperación entre los órganos de recurso de primera instancia: "La evaluación pone de manifiesto que los sistemas en los cuales son los órganos administrativos de recurso, en vez de los órganos jurisdiccionales ordinarios, los encargados de la protección jurídica en primera instancia en relación con los procedimientos de contratación pública tienden a ser más eficaces en términos tanto de duración del procedimiento como de criterios de adjudicación. Por este motivo, tal como se anunció en la Estrategia para el Mercado Único, la Comisión promoverá la cooperación y el establecimiento de una red entre los órganos de recurso de primera instancia con el fin de mejorar el intercambio de información y las mejores prácticas relacionadas con aspectos concretos de la aplicación de las Directivas sobre procedimientos de recurso y, más en general, a fin de garantizar el funcionamiento eficiente de los procedimientos nacionales de recurso. Las buenas prácticas pertinentes serán difundidas a través de la red. Dichas buenas prácticas pueden constituir una fuente de inspiración y de influencia para que los Estados miembros mejoren sus sistemas de recurso nacionales. En este contexto, se prestará especial atención al reforzamiento de los órganos administrativos de recurso en primera instancia».

En definitiva, se ha creado un recurso que tiene estos cuatro caracteres generales: revisor, excluyente, potestativo y eficaz(20).

La doctrina se ha pronunciado, en general, de forma positiva sobre la creación de los TARC, y en especial, a la vista de la relevante tarea que han venido realizando a lo largo de estos años(21). Las medidas que se han propuesto pueden resumirse en estos aspectos (22):

1) Supresión de los TARC de ámbito local.

2) Refuerzo de la independencia de los TARC.

(20) SANTAMARÍA PASTOR, Los recursos especiales en materia de contratos del sector público, págs. 65-74.

(21) Véase por todos, GIMENO FELIÚ, Sistema de Control de la Contratación Pública en España, op. cit., págs. 169-179.

(22) GIMENO FELIÚ, tras valorar positivamente el modelo de TARC y su funcionamiento, apunta algunas disfunciones para lo que ofrece algunas medidas a tomar en la futura LCSP (págs. 179-189). Asimismo BERENGUER AMAT, A., señala diversas cuestiones controvertidas del recurso especial tanto respecto de su ámbito como de carácter procesal («El recurso especial en materia de contratación, como instrumento de control eficaz para combatir la corrupción. Cuestiones controvertidas», en Revista Jurídica de Cataluña, núm. 1/2017, págs. 73-86) 
3) Supresión de la cuestión de nulidad.

4) Ampliación del ámbito de contratos de los que pueden conocer, de modo que no se limiten sólo a los contratos sujetos a regulación armonizada (23).

5) Ampliación de los actos impugnables que alcancen también a las modificaciones contractuales y a los encargos.

La actividad desarrollada por los Tribunales Administrativos de recursos contractuales ha sido muy positiva. Además del TARC estatal (y que presta servicios asimismo a diversas Comunidades Autónomas) se han constituido diversos TARC de ámbito autonómico (País Vasco, Cataluña, Andalucía, Canarias, Aragón, Navarra, Madrid, Castilla y León y Extremadura) y en los Territorios Históricos del País Vasco (24).

$Y$, asimismo, en algunas Comunidades Autónomas se han creado TARC por las Diputaciones provinciales y por algunos municipios.

\section{La regulación de los TARC en la LCSP}

La LCSP es continuista sobre el modelo fijado para los TARC en el TRLCS/2017, puesto que mantiene el sistema de recurso especial encomendándolo a un órgano no jurisdiccional especializado. Sin embargo, la nueva LCSP introduce importantes cambios, de forma relevante sobre la regulación del recurso especial y sólo algunos en cuanto a los TARC, incorporando tanto la doctrina de los propios TARC, las recomendaciones del Consejo de Estado y también algunas disposiciones reglamentarias del Real Decreto 814/2015.

Para ello, la exposición que sigue se va a centrar en el estudio de los TARC tanto en cuanto a su composición e independencia como, sobre todo, de los poderes que les atribuye la LCSP.

\footnotetext{
(23) Así lo postula BERNAL BLEY, M. A., "Hacia la unidad del Sistema de recursos en material de contratación pública", en la obra colectiva Las vías administrativas de recurso a debate. Actas del XI Congreso de la Asociación Española de Profesores de Derecho Administrativo. Zaragoza, 5 y 6 de febrero de 2016, Ed. INAP, Madrid, 2016, págs. 489-498. Es que en otro caso, como indica VALCÁRCEL FERNÁNDEZ, P., el recurso especial es sólo para la guinda del pastel y, por ello, postula su extensión a todos los contratos y a todas las fases de los contratos ( $E$ El recurso especial en materia de contratos públicos: en la senda del derecho a una buena administración", op. cit., págs. 315-321).

(24) Sobre el estado actual de los diversos Tribunales Administrativos, central, autonómicos y locales, véanse LÓPEZ MENUDO, «Transposición irregular de la normativa europea sobre el Tribunal de recursos contractuales: ¿Un modelo para la resolución de los recursos administrativos en general?», op. cit., págs. 1427-1433 y BERENGUER AMAT, A., "El recurso especial en materia de contratación, como instrumento de control eficaz para combatir la corrupción. Cuestiones controvertidas", op. cit., págs. 86-88.
} 


\section{Los TARC (25)}

La LCSP, a diferencia del TRLCSP, diferencia en dos preceptos la regulación de los TARC. Por un lado, el art. 45 se refiere alTACRC, en términos prácticamente idénticos al apartado 1 del art. 41 TRLCSP. Las novedades que se introducen son puntuales y de poca relevancia (26). Por tanto, sigue configurado como un órgano especializado, colegiado, independiente y formado por Licenciados en Derecho, preferentemente con conocimientos de Derecho Administrativo relacionado con la contratación pública (27). Su plazo es de 6 años y no es prorrogable y durante el mismo están en la situación de servicios especiales.

Ahora la disposición adicional 29. a permite la creación de Tribunales territoriales, que deberán reunir similares requisitos de independencia que eITACRC.

(25) Sobre los TARC se han publicado numerosos estudios desde el año 2010 en que la Ley 34/2010 los introdujo en España. Por ejemplo, la Revista Documentación Administrativa dedicó a los Tribunales Administrativos de Recursos Contractuales su número 288/2010. A partir de dicha fecha se han multiplicado los estudios, siendo el más completo el libro de SANTAMARÍA PASTOR, J. A., Los recursos especiales en materia de contratos del sector público, op. cit., donde se contiene un análisis exhaustivo, crítico y excelente de estos Tribunales Administrativos. Una visión directa desde la presidencia de un TARC puede verse en GIMENO FELIÚ, J. M., Sistema de Control de la Contratación Pública en España, op. cit. También ténganse en cuenta otros estudios más reducidos pero siempre de interés: SANTAMARÍA PASTOR, J. A., "El sistema de Tribunales Administrativos de recursos contractuales", en Asamblea. Revista parlamentaria de la Asamblea de Madrid núm. 32/2015, págs. 41-77; HERNAÉZ SALGUERO, E., "El recurso administrativo especial en materia de contratación a la luz de las resoluciones dictadas por el Tribunal Administrativo de Contratación Pública de la Comunidad de Madrid», en la misma Revista núm. 29/2013, págs. 163-208; SANTIAGO FERNÁNDEZ, M. J., "Los tribunales administrativos de recursos contractuales como mecanismos de control en la contratación pública. Perspectiva actual y de futuro", en Auditoría Pública núm. 66/2015, págs. 105-118; CANDELA TALAVERO, J. E., El Recurso Especial como Instrumento de Control en Materia de Contratación Pública, Ed. Fundación de Asesores Locales, Málaga, 2015; GIMENO FELIÚ, J. M., «Informe especial. Sistema de control de la contratación pública en España (Cinco años de funcionamiento del recurso especial en los contratos públicos. La doctrina fijada por los órganos de recursos contractuales. Enseñanzas y propuestas de mejora)", Observatorio de Contratación Pública, diciembre 2015, así como "Los tribunales administrativos especiales de contratación pública ante las previsiones del informe de la Comisión para la reforma de las administraciones públicas: balance y perspectivas", en Revista catalana de dret public, núm. 47/2013, págs. 87-102; VALCÁRCEL FERNÁNDEZ, P., «El recurso especial en materia de contratos públicos: en la senda del derecho a una buena administración", op. cit., págs. 303-367; LÓPEZ MENUDO, F., «Transposición irregular de la normativa europea sobre el Tribunal de recursos contractuales: ¿Un modelo para la resolución de los recursos administrativos en general?", op. cit., págs. 1411-1434: y BERENGUER AMAT, A., "El recurso especial en materia de contratación, como instrumento de control eficaz para combatir la corrupción. Cuestiones controvertidas", op. cit., págs. 69-90.

(26) Se reduce la actividad profesional para ser vocal de 15 a 10 años, se exige sentencia firme para ser separado del cargo por delito, se indica que los vocales pasan a la situación de servicios especiales, y que formará parte del Tribunal el Secretario General. La figura del Secretario General se recogía ya en el art. 3.1 del Real Decreto 814/2015.

(27) Una crítica a la organización interna del TACRC la realiza GONZÁLEZ-DELEITO DOMíNGUEZ, N., "La organización, ¿el caballo de Troya de la independencia de los tribunales administrativos de contratación?», en Actualidad Administrativa núm. 3/2017, págs. 1-14. 
Por su parte, el art. 46.1 y 2 se refiere, eso sí sin carácter básico, a los órganos de las Comunidades Autónomas, que pueden no obstante celebrar convenio con el Estado para que sus recursos sean conocidos por el TACRC (apartado 2). Igualmente ambos apartados contienen muy pocas novedades. Se sigue, por tanto, posibilitando que el órgano sea unipersonal o colegiado, y se resalta la necesidad de su independencia.

Las novedades principales (28) se encuentran en el ámbito local, al que se dedica el apartado 4 del art. 46, con carácter básico. Por un lado, persiste la concesión de la competencia para decidir sobre el órgano competente en favor de las Comunidades Autónomas, y a falta de ésta en el órgano autonómico correspondiente.

La novedad radica en dos aspectos. Por un lado, los municipios de gran población y las Diputaciones Provinciales pueden crear su propio órgano especializado («sin perjuicio de lo dispuesto en el párrafo siguiente" y "en todo caso", dice este apartado 4). No obstante, la regulación de su composición y requisitos se deja en manos de la legislación autonómica o, en su defecto, deberán aplicarse las exigencias establecidas para elTACRC. Por otro, el resto de municipios puede atribuir la competencia al órgano especializado creado por la Diputación Provincial.

Debe llamarse la atención sobre la proliferación de estos TARC (autonómicos $y$, sobre todo, locales), puesto que ahora replican la organización territorial. Por ello debe recordarse que lo más importante es que los mismos sean independientes, es decir, estén compuestos por Presidente y Vocales que sean realmente independientes y, además, tengan conocimientos en materia de contratación pública. Esta exigencia de independencia se encuentra en la LCSP, pero sobre todo viene impuesta por las Directivas de recursos. Esto significa que los TARC de cualquier ámbito que no respeten las características de independencia exigidas por las Directivas no se ajustan a ellas, y por tanto suponen una vulneración del Derecho de la Unión Europea.Y para ello, como parámetro de comprobación de independencia, pueden servir las consideraciones efectuadas por el TJUE en su Sentencia de 6 de octubre de 2015 (asunto C-203/14) sobre el TARC de Cataluña, que se ha examinado más arriba.

La disposición adicional 23. ${ }^{a}$ prevé que los TARC acuerden fórmulas de coordinación y colaboración para la unificación de doctrina.

(28) Aunque se mantiene la regulación relativa a las Ciudades Autónomas de Ceuta y Melilla (apartado 3), y se adiciona otra referente a los Territorios Históricos de la Comunidad Autónoma del País Vasco (apartado 5). 


\section{Los poderes de los TARC}

Los poderes de los TARC van a ser comparados con los que tendría un juez o tribunal de lo contencioso administrativo a la luz de lo establecido en la LJCA (29). En definitiva, se trata de comparar las atribuciones que efectúa la LCSP, con las de la LJCA.Y ello porque aunque se trate de Tribunales administrativos, y que se rigen por las normas de los órganos colegiados establecidas en la Ley 40/2015, de 1 de octubre, de Régimen Jurídico del Sector Público, sin embargo cumplen funciones que también pueden ser atribuidas a órganos jurisdiccionales, como de hecho se efectúa en otros ordenamientos jurídicos, puesto que las Directivas de recursos dejan a la libre decisión de los Estados miembros el carácter jurisdiccional o no de los órganos resolutorios de los recursos. $Y$ por otra parte, aunque bien es cierto que sólo a los efectos de considerarlo como órgano jurisdiccional para plantear la cuestión prejudicial, el TJUE ha aceptado esta condición del TARC de Cataluña en su Sentencia de 6 de octubre de 2015. Y efectuaré esta comparación aun siendo consciente de que el objeto de la competencia de los TARC es el recurso especial que constituye un recurso administrativo(30) y que, por tanto, a diferencia de los recursos contencioso-administrativos debe ser resuelto en el plazo de dos meses desde su interposición, con la consecuencia en caso contrario del silencio administrativo negativo (art 57.7 LCSP).

\subsection{SU COMPETENCIA}

Los TARC son órganos especializados cuyo único objeto es resolver el recurso especial. Frente a los jueces y tribunales de lo contenciosoadministrativo que conocen de todos los recursos contencioso-administrativos en materia de contratación pública, en muchos casos tras la previa vía administrativa obligada en el caso de los recursos de alzada, los TARC sólo son competentes para resolver algunos recursos, aquellos que se interponen en relación con los contratos que superen una determinada cuantía.

El recurso especial se articula como vía única, que incorpora la denominada cuestión de nulidad que ahora queda suprimida. Así pues, hay un único recurso en sus dos variantes de precontractual y postcontrac-

(29) GIMENO FELIÚ ha expresado que el alcance de la competencia revisora de los TARC tiene que ser equivalente con el modelo judicial (Sistema de Control de la Contratación Pública en España, op. cit., págs. 50-58).

(30) El Real Decreto 814/2015 insiste de forma reiterativa en su carácter de recurso administrativo (especialmente en su art. 2). 
tual. No obstante, se mantiene su carácter de recurso potestativo(31), alternativo al contencioso-administrativo(32) y sustitutivo de los recursos administrativos. Ello significa que la competencia de los TARC no es obligatoria sino potestativa, de modo que el recurrente puede optar por acudir a la vía del recurso especial o bien ir directamente al recurso contencioso-administrativo. Bien es cierto que las ventajas de uno y otro son diferentes, en especial en lo que respecta a la suspensión automática en el caso de que el acto recurrido sea el acto de adjudicación.

No obstante, se trata de una vía previa administrativa resuelta por un Tribunal Administrativo independiente, que opera casi como una primera instancia cuasijurisdiccional puesto que las resoluciones dictadas por los TARC son conocidas en todos los casos por las Salas de lo contencioso-administrativo bien de los Tribunales Superiores de Justicia (art. 10.1.l) y k) LJCA) o de la Audiencia Nacional (art. 11.1.f) LJCA). Debe tenerse en cuenta que, en el caso de los contratos locales cuya resolución no competa a los TARC o cuando el recurrente opte directamente por la vía jurisdiccional, la competencia es siempre de los Juzgados de lo Contencioso-Administrativo (art. 8.1 LJCA). Además, el recurso especial es un recurso de única instancia, y contra su resolución definitiva no cabe revisión de oficio.

Además, frente a las resoluciones de los TARC estimatorias de los recursos están, asimismo, legitimadas para recurrir las Administraciones Públicas (arts. 19.4 y 44.1 LJCA), lo que evidencia también su carácter cuasijurisdiccional.

La LCSP ha introducido importantes cambios en los contratos sujetos a esta vía especial. Por un lado, ha devaluado la división estricta entre contratos sujetos o no a regulación armonizada, puesto que este criterio ya no es el que se utiliza para definir aquellos contratos sujetos a la vía del recurso especial. Ahora el elemento determinante será el de la cuantía de los contratos.

Sigue, por tanto, la dualidad del sistema de recursos:

1) Los contratos que superen una determinada cuantía quedan sometidos al recurso especial, de forma potestativa (art. 44.1).

2) Los contratos que no superen dicha cuantía siguen las reglas generales de recursos administrativos de la LPAC (Ley 39/2015, de 2 de octubre) y de la LJCA (art. 44.6 párr. $1^{\circ}{ }^{\circ}$.

(31) Aquí se modifica la propuesta del Anteproyecto que concebía el recurso especial como obligatorio, lo que había contado además con el beneplácito del Consejo de Estado.

(32) Este carácter potestativo permite que puedan coincidir simultáneamente un recurso especial (o recurso contra una resolución de unTARC) y un recurso contencioso-administrativo directo frente al mismo acto. Es lo que se examinó en la STS de 14 de noviembre de 2013, que resuelve una cuestión de competencia entre las Salas de lo contencioso-administrativo de la Audiencia Nacional y del Tribunal Superior de Justicia de Madrid. 
Pero, además, la LCSP ha roto la dualidad del régimen administrativo o civil de los recursos contra los actos de los poderes adjudicadores no Administraciones Públicas(33), puesto que ahora en todo caso los recursos contra todas sus decisiones en materia contractual se residencian en vía administrativa: bien en el recurso especial (por razón de la cuantía y no siendo ya decisivo que el contrato esté sujeto a regulación armonizada) ante el TARC que corresponda (art. 47.1) o bien en los recursos de alzada, conforme a las previsiones de la LPAC (art. 44.6 párr. 2. ${ }^{\circ}$ LCSP), siendo además todas ellas enjuiciables ante la jurisdicción contenciosoadministrativa (art. 27).

Ahora el art. 44.1 LCSP dice así:

"Serán susceptibles de recurso especial en materia de contratación, los actos y decisiones relacionados en el apartado 2 de este mismo artículo, cuando se refieran a los siguientes contratos que pretendan concertar las Administraciones Públicas o las restantes entidades que ostenten la condición de poderes adjudicadores:

a) Contratos de obras cuyo valor estimado sea superior a tres millones de euros, y de suministro y servicios, que tenga un valor estimado superior a cien mil euros.

b) Acuerdos marco y sistemas dinámicos de adquisición que tengan por objeto la celebración de alguno de los contratos tipificados en la letra anterior, así como los contratos basados en cualquiera de ellos.

c) Concesiones de obras o de servicios cuyo valor estimado supere los tres millones de euros.

Serán igualmente recurribles los contratos administrativos especiales, cuando, por sus características no sea posible fijar su precio de licitación o, en otro caso, cuando su valor estimado sea superior a lo establecido para los contratos de servicios.

Asimismo serán susceptibles de recurso especial en materia de contratación los contratos subvencionados a que se refiere el artículo 23, y los encargos cuando, por sus características no sea posible fijar su importe o, en otro caso, cuando este, atendida su duración total más las prórrogas, sea igual o superior a lo establecido para los contratos de servicios».

(33) También para las demás entidades del sector público, como establece el art. 321.5 LCSP, los actos de preparación y adjudicación se residencian ahora en la vía administrativa y después contencioso-administrativa (art. 27.1.e). 
Conviene calificar esta medida como buena, porque no cabe olvidar que el recurso especial es gratuito (art. 44.7 LCSP) (34), mientras que los recursos jurisdiccionales comportan gastos e incluso posible condena en costas en el caso de que el recurrente no vea estimado su recurso contencioso-administrativo.

\subsection{LOS ACTOS IMPUGNABLES}

La LJCA contempla un amplio abanico sobre la actuación administrativa impugnable que va desde los reglamentos y los actos, a la inactividad y la vía de hecho (arts. 25-30).

El art. 44.2 LCSP establece como actos impugnables mediante el recurso especial los siguientes:

«a) Los anuncios de licitación, los pliegos y los documentos contractuales que establezcan las condiciones que deban regir la contratación.

b) Los actos de trámite adoptados en el procedimiento de adjudicación, siempre que estos decidan directa o indirectamente sobre la adjudicación, determinen la imposibilidad de continuar el procedimiento o produzcan indefensión o perjuicio irreparable a derechos o intereses legítimos. En todo caso se considerará que concurren las circunstancias anteriores en los actos de la mesa o del órgano de contratación por los que se acuerde la admisión o inadmisión de candidatos o licitadores, o la admisión o exclusión de ofertas, incluidas las ofertas que sean excluidas por resultar anormalmente bajas como consecuencia de la aplicación del artículo 149.

c) Los acuerdos de adjudicación.

d) Las modificaciones basadas en el incumplimiento de lo establecido en los artículos 204 y 205 de la presente Ley, por entender que la modificación debió ser objeto de una nueva adjudicación.

e) La formalización de encargos a medios propios en los casos en que estos no cumplan los requisitos legales.

f) Los acuerdos de rescate de concesiones".

(34) Lo que supone la supresión de la tasa que sólo existía para los recursos ante el Tribunal Administrativo de Cataluña. Véase al respecto BERENGUER AMAT, A., «El recurso especial en materia de contratación, como instrumento de control eficaz para combatir la corrupción. Cuestiones controvertidas", op. cit., págs. 85-86. 
Como puede verse, la LCSP limita los actos impugnables a las actuaciones sin referencia a actos, con lo cual debe entenderse que incluye tanto los actos expresos (decisiones) como los presuntos. Asimismo la vía de hecho (por ejemplo, una adjudicación directa sin procedimiento o una modificación sin seguirse los trámites de la Ley) también pueden ser objeto de recurso especial. Más difícil cabida tienen los posibles recursos contra la inactividad. Incluso en los supuestos de vía de hecho cabe preguntarse por la vía acelerada prevista en el art. 30 LJCA que permite acudir al juez formulando o no requerimiento a la Administración, y en el caso de requerirla, el transcurso de diez días sin atender el requerimiento habilita para la interposición de esta modalidad de recurso contencioso-administrativo.

Por otra parte, es obligado llamar la atención sobre la amplitud del recurso contra los actos de trámite que ahora prevé la LCSP, en la que se "supera» la dicción del art. 25 LJCA, siguiendo lo establecido por la STJUE de 5 de abril de 2017.

En cuanto a las actuaciones impugnables conviene resaltar las novedades de la LCSP sobre el TRLCSP. Por un lado, la LCSP ha satisfecho las peticiones de la doctrina (e incluso de la Ley Foral de Contratos Públicos de Navarra) de incluir tanto las modificaciones como los encargos que no reúnan las condiciones legalmente establecidas para su adopción. Y, por otro, ha adicionado un nuevo supuesto inesperado como es el de "los acuerdos de rescate de concesiones".

\subsection{El EXAMEN DE LEGALIDAD}

Los TARC son un órgano que resuelve los recursos especiales que se le presentan con arreglo a Derecho. Son por tanto órganos jurídicos, y en consecuencia su composición obedece a estos parámetros, debiendo su Presidente y Vocales ser Licenciados o Graduados en Derecho (al menos esto se exige para el TACRC y lo mismo debiera ser imprescindible para losTARC autonómicos y locales).

El art. 70.2 LJCA señala que la sentencia estimará el recurso contencioso-administrativo si la actuación incurriera en cualquier infracción del ordenamiento jurídico, incluso la desviación de poder.

La LCSP no limita los motivos de recurso, y por tanto los TARC pueden examinar cualquier infracción del ordenamiento jurídico en relación con la actuación que se les someta a enjuiciamiento. Por un lado, el recurso especial sustituye a los recursos administrativos ordinarios que no tienen límites (en ello se diferencian del recurso extraordinario de revisión).

Por otra parte, el recurso especial es una vía previa cuasijurisdiccional, y no tendría sentido que se limitaran los motivos de recurso, dejando así 
una parte de las posibles infracciones al conocimiento único y posterior de los Tribunales de Justicia (de las Salas).

\subsection{LAS DECISIONES QUE PUEDEN ADOPTAR: CONTENIDO DE SUS RESOLUCIONES}

Los TARC pueden adoptar las tres decisiones que contemplan las Directivas de recursos: anulación, indemnización y medidas provisionales. Con ello la LCSP cumple de forma escrupulosa con las exigencias del art. 2.1 de la Directiva 89/665/CEE (35).

Los recursos son ágiles y rápidos: breves plazos de interposición (art. 50 LCSP), breve tramitación electrónica (art. 56), y breve plazo de resolución (art. 57). Nada que ver con los recursos contencioso-administrativos, donde los plazos ni siquiera se cumplen en el procedimiento abreviado del art. 78 LJCA. Pero lo más importante es que los TARC, con carácter general, resuelven los recursos en un plazo muy breve de tiempo. Esta es una de las conquistas que deben mantener, sobre todo ante el nuevo reto de una previsible afluencia de un mayor número de recursos con la ampliación del objeto del recurso especial.

Por otro, los recursos son eficaces puesto que, además de su celeridad a la que se une su carácter suspensivo automático en caso de recurrirse los acuerdos de adjudicación, la resolución de los TARC es «directamente ejecutiva" (art. 59.2 LCSP).

\subsubsection{Medidas cautelares}

En cuanto a las medidas cautelares la amplitud de las que pueden adoptar los TARC es muy grande. Por un lado, cabe la adopción de medidas provisionalísimas, antes de la interposición del recurso especial (art. 49), y también con motivo de su interposición (art 56.3). La LCSP contempla las medidas cautelares desde una perspectiva muy amplia: «Tales medidas irán dirigidas a corregir infracciones de procedimiento o impedir que se causen otros perjuicios a los intereses afectados, y podrán estar incluidas, entre ellas, las destinadas a suspender o a hacer que se suspenda el procedimiento de adjudicación del contrato en cuestión o la ejecución de cualquier decisión adoptada por los órganos de contratación»

(35) La STJUE de 26 de noviembre de 2015 (asunto C-166/14) explica los tres tipos de recursos que la Directiva 89/665/CEE exige a los Estados miembros: de adopción de medidas provisionales, de anulación de las decisiones ilegales y de indemnización de daños y perjuicios (apartado 29). Y añade que existen diferencias entre las demandas por daños y perjuicios y las demandas de anulación, en concreto en cuanto a la seguridad jurídica que afecta a los plazos (apartados 39-44). 
(art. 49.1). Por tanto, este precepto encaja con la genérica previsión del art. 129 LJCA que se refiere a cuantas medidas aseguren la efectividad de la sentencia. Sin embargo, el juego de la suspensión automática del recurso especial contra los actos de adjudicación y de las medidas cautelares de suspensión en vía judicial es bien distinto.

En el caso de solicitarse medidas cautelares en vía judicial frente a las resoluciones de los TARC opera asimismo el art. 129 LJCA. EI TS se ha pronunciado en diversas ocasiones (Sentencias de 23 de octubre de 2014, de 5 de noviembre de 2014, de 22 de enero de 2015 - Rec. 3017/2013- y de 22 de enero de 2015 - Rec. 3129/2013-), señalando que las resoluciones de los TARC gozan de presunción de acierto y apariencia de buen derecho, lo que hace muy difícil su suspensión(36).

\subsubsection{Indemnización}

También los TARC pueden conceder indemnizaciones a solicitud de los interesados. El art. 58.1 dispone que: «El órgano competente para la resolución del recurso, a solicitud del interesado, podrá imponer a la entidad contratante la obligación de indemnizar a la persona interesada por los daños y perjuicios que le haya podido ocasionar la infracción legal que hubiese dado lugar al recurso, resarciéndole, cuando menos, de los gastos ocasionados por la preparación de la oferta o la participación en el procedimiento de contratación» (párr. 1. ${ }^{\circ}$ ). Como puede verse se trata de una solicitud de indemnización anudada a un recurso de anulación (37), lo que significa que no se contempla su exigencia ante los TARC de forma independiente (38).

No obstante, en la práctica, del examen de las Memorias de 2016 y 2017 de diversos TARC se desprende que su actuación parece haberse limitado a los recursos de anulación y a las medidas cautelares, pero no han otorgado indemnizaciones (parece que tampoco los recurrentes las han solicitado).

(36) Véase al respecto los trabajos de GALLEGO CÓRCOLES, I., "Suspensión cautelar de las resoluciones de los Tribunales Administrativos de Recursos Contractuales", en Contratación Administrativa Práctica núm. 136/2015 y de FERNÁNDEZ-LOMANA, GARCÍA, M., "La suspensión cautelar de las resoluciones del Tribunal Administrativo Central de Recursos Contractuales», en Actualidad Administrativa núm. 6/2016.

(37) Sin embargo SANTAMARÍA PASTOR, sin negar la competencia de los TARC para dictar resoluciones de contenido indemnizatorio, señala que esta vía va a tener una aplicación escasa y que normalmente la acción de indemnización se planteará en momentos posteriores al recurso especial (Los recursos especiales en materia de contratos del sector público, pág. 198).

(38) El art. 33 del Real Decreto 814/2015 dice claramente que la indemnización sólo podrá ser concedida a solicitud del recurrente "en el caso de estimar el recurso". 
Debe tenerse en cuenta la doctrina sentada por la STJUE de 26 de noviembre de 2015 (C-166/14) donde se examina la exigencia de indemnización de daños y perjuicios prevista en el art. 6.2 de la Directiva 89/665. El Tribunal afirma que los Estados pueden supeditar la presentación de la demanda de indemnización a que la decisión impugnada sea anulada previamente (apartado 35). Pero, a continuación, añade que el principio de equivalencia exige dar efectividad a las demandas de indemnización que no tienen los mismos requisitos de admisibilidad que las demandas de recursos. Por tanto, no se puede privar de efectividad al derecho a indemnización dejando a la persona perjudicada sin el acceso a uno de los remedios de la Directiva 89/665. Y así responde a la cuestión prejudicial formulada en los siguientes términos:

«El Derecho de la Unión Europea, en particular el principio de efectividad, se opone a una normativa nacional que supedita la presentación de una demanda de indemnización de daños y perjuicios por la infracción de una norma del Derecho de contratación pública a que se haya declarado previamente la ilegalidad del procedimiento de adjudicación del contrato considerado debido a que no se ha publicado previamente un anuncio de licitación, cuando la solicitud de dicha declaración de ilegalidad está sometida a un plazo de preclusión de seis meses que empieza a correr el día siguiente al de la adjudicación del contrato público controvertido, y ello con independencia de si el demandante podía conocer o no la existencia de la ilegalidad relativa a dicha decisión del poder adjudicador».

\subsubsection{Anulación: ¿carácter simplemente revisor?}

Si examinamos estos poderes de los TARC de forma comparativa con lo dispuesto en el art. 71 LJCA que dispone lo que pueden acordar los jueces y tribunales cuando estimen un recurso contencioso-administrativo, cabe afirmar que el recurso especial no se limita a ser solo un recurso de anulación (aunque algunos autores hablen del mero carácter revisor de los TARC) sino que, al menos parcialmente, es también un recurso de plena jurisdicción. Y ello porque además de anular el acto pueden estimar la pretensión de resarcir los daños y perjuicios.

Acaba de apuntarse que la equiparación es sólo parcial, puesto que el juez o tribunal puede además efectuar dos pronunciamientos que parece que en principio losTARC no pueden adoptar: 
a) El reconocimiento de una situación jurídica individualizada.

b) La fijación de un plazo para la emisión de un acto o la práctica de una actuación administrativa obligatoria.

En la práctica los TARC se limitan a dictar resoluciones de simple anulación, sin que su resolución alcance a declarar la situación jurídica que puedan demandarle los recurrentes(39), como por ejemplo la adjudicación del contrato cuando resulte evidente que el recurrente debiera ser el adjudicatario del mismo(40). El Tribunal se limita a anular el acto recurrido y deja la decisión final en manos del órgano de contratación.

Y menos losTARC fijan plazos para que los órganos de contratación efectúen actos o actuaciones obligatorias en materia de contratación pública.

Con ser esto cierto, tal vez sus consecuencias no sean tan relevantes como a primera vista pudiera parecer, toda vez que las decisiones anulatorias de los TARC deben ser cumplidas de inmediato (son ejecutivas) por los órganos de contratación, que deberán dictar el acto consiguiente derivado de su ejecución. Así lo indica respecto de la adjudicación el art. 150.4 LCSP, que se refiere a la adjudicación del contrato por el órgano de contratación a otro licitador como consecuencia de la revolución del recurso especial.

\subsubsection{Sanciones versus condena en costas}

Para los procesos jurisdiccionales el art. 139 LJCA contempla la condena en costas a la parte que haya visto rechazadas todas sus pretensiones, salvo que el Juez o Tribunal aprecie razonadamente la existencia de dudas de hecho y de derecho(41). La LCSP no contempla ninguna medida igual, pero algunos de sus efectos pueden verse en diversos preceptos de la LCSP, aunque sólo para el recurrente y no para las entidades cuyas actuaciones son objeto de recurso.

(39) Ello se deriva del carácter puramente revisor de los TARC, por lo que no declaran situaciones jurídicas individualizadas (SANTAMARÍA PASTOR, Los recursos especiales en materia de contratos del sector público, pág. 196). En el mismo sentido se pronuncia VALCÁRCEL FERNÁNDEZ, indicando además que ello supone una limitación respecto de los recursos administrativos ordinarios ( $\mathrm{El}$ recurso especial en materia de contratos públicos: en la senda del derecho a una buena administración", op. cit, págs. 338-339).

(40) Por ejemplo en el caso de que una oferta sea considerada anormalmente baja por el TARC y la consecuencia evidente sea la de adjudicar el contrato al siguiente licitador en puntuación. $\mathrm{O}$ la adjudicación del contrato al licitador que ha resultado adjudicatario pero que ve su oferta rechazada por ser considerada indebidamente como anormalmente baja.

(41) Es claro que las costas procesales inciden en la posible interposición de recursos contenciosoadministrativos. Véase al respecto CIERCO SIERA, C., "Las costas procesales y el derecho de acceso a la justicia administrativa», en AGUDO GONZÁLEZ, A., Control Administrativo y Justicia Administrativa, Ed. INAP, Madrid, 2016, págs. 103-149. 
Así pues, la entidad contratante del sector público que ve estimado el recurso y anulada en su integridad la actuación que ha realizado no se ve condenada por ello, de modo que el recurrente deberá cargar con sus gastos de abogado (por ejemplo) (42).

La LCSP permite a los TARC imponer multas a los recurrentes que actúen con mala fe o temeridad bien en la interposición del recurso o en la solicitud de medidas cautelares (art. 58.2). Además, este precepto ha elevado las cuantías de las multas, que van ahora desde 1.000 a 30.000 euros.

\subsubsection{Otras cuestiones resueltas por la LCSP}

La LCSP ha dado solución a dos cuestiones que no estaban previstas en el TRLCSP. En primer lugar, el derecho de acceso al expediente, donde se incorpora la práctica derivada del art. 29.3 del Real Decreto 814/2015, de facilitar el acceso al expediente al recurrente en la sede del TARC, lo que evita la devolución de los autos al órgano de contratación y el retraso en el dictado de la resolución de fondo. El art. 52.3 LCSP dispone lo siguiente: "El incumplimiento de las previsiones contenidas en el apartado 1 anterior no eximirá a los interesados de la obligación de interponer el recurso especial dentro del plazo legalmente establecido. Ello no obstante, el citado incumplimiento podrá ser alegado por el recurrente en su recurso, en cuyo caso el órgano competente para resolverlo deberá conceder al recurrente el acceso al expediente de contratación en sus oficinas por plazo de diez días, con carácter previo al trámite de alegaciones, para que proceda a completar su recurso. En este supuesto concederá un plazo de dos días hábiles al órgano de contratación para que emita el informe correspondiente y cinco días hábiles a los restantes interesados para que efectúen las alegaciones que tuvieran por conveniente".

Se trata, por consiguiente, de un aspecto muy positivo de la nueva LCSP, puesto que evita los retrasos en la impartición de la justicia material.

La otra cuestión es la adopción de una medida similar a la que se efectúa en el ámbito judicial en materia de confidencialidad. La confidencialidad sigue en la vía jurisdiccional, sin perjuicio de que sea el Juez o Tribunal quien decida sobre qué información del expediente administrativo es confidencial o no. Pues bien, ahora el art. 56.3 LCSP concede ese poder a

(42) A mi juicio, del art. 58 LCSP no se puede extender una condena en costas a la Administración u otra entidad recurrida. La indemnización que contempla es de otro tipo, y por tanto la he incardinado de forma comparativa con el art 71 LJCA. 
Ios TARC: "Corresponderá a dicho órgano resolver acerca de cómo garantizar la confidencialidad y el secreto de la información que obre en el expediente de contratación, sin que por ello, resulten perjudicados los derechos de los demás interesados a la protección jurídica efectiva y al derecho de defensa en el procedimiento".

\subsection{LA EJECUCIÓN DE SUS RESOLUCIONES}

Las sentencias de los Jueces y Tribunales son ejecutivas como tales sentencias, salvo cuando sea posible la interposición de recursos contra ellas, en cuyo caso su ejecución provisional es bastante dificultosa. Ello significa que, por ejemplo, en el supuesto de que se opte por interponer recurso contra una decisión de un ente local en lugar de utilizar la vía del recurso especial, la sentencia del Juzgado (que es el competente en virtud del art. 8 LJCA) será apelable a la vista de las cuantías establecidas por el art. 81 LJCA. En definitiva, no será directamente ejecutiva, con lo que la ilegalidad declarada en primera instancia no queda sin efecto de forma inmediata dado el carácter suspensivo del recurso de apelación. Y algo similar ocurre en el caso de las sentencias de las Salas de los Tribunales Superiores de Justicia o de la Audiencia Nacional que son recurribles en casación.

Es, por ello, que la opción por la vía judicial encuentra estos importantes escollos prácticos en orden a la eficacia y a la rapidez en la reparación de la infracción cometida por los órganos de contratación.

Frente a ello, el art. 59 LCSP declara que la resolución de los TARC es inmediatamente ejecutiva. Ello significa que debe ser ejecutada por los órganos de contratación. El posible recurso contencioso-administrativo contra ella no paraliza su ejecución, salvo que así lo acuerde expresamente la Sala judicial mediante la adopción de alguna de las medidas cautelares previstas en el art. 129 LJCA, que es muy difícil que adopten a la vista del carácter de órgano independiente y especializado de los TARC (43). Esto constituye una gran ventaja para los recurrentes, puesto que se les garantiza una aplicación inmediata de la resolución y, seguramente, un amparo efectivo y rápido de su derecho, con la anulación de la actuación ilegal de la entidad del sector público de que se trate.

El problema se encuentra en la gran diferencia en orden a garantizar la efectiva ejecución de las resoluciones de los TARC o de las sentencias

(43) MARTÍN VALERO, A. I., recoge como especialidades procesales en vía jurisdiccional las relativas a la competencia jurisdiccional, las medidas cautelares, la legitimación activa y pasiva y las costas («Especialidades procesales en los recursos frente a las resoluciones de los Tribunales de Recursos Contractuales», en Actualidad Administrativa núm. 12/2017). 
judiciales. Derivada de la potestad jurisdicción de juzgar y hacer ejecutar lo juzgado del art. 117 CE, el art. 103 (y siguientes) de la LJCA recoge importantes consecuencias derivadas de un posible incumplimiento, e incluso el art. 112 ordena al juez o tribunal adoptar las medidas necesarias para lograr la efectividad de lo mandado en la sentencia llegando a la exigencia de responsabilidad penal.

Nada de ello se contempla en la LCSP para los TARC. Únicamente la LCSP ha establecido lo siguiente: "En caso de estimación total o parcial del recurso, el órgano de contratación deberá dar conocimiento al órgano que hubiera dictado la resolución, de las actuaciones adoptadas para dar cumplimiento a la misma» (art. 57.4).

Llama la atención que la LCSP no haya incorporado las disposiciones del art. 36 del Real Decreto 814/2015 en orden a la ejecución de las resoluciones de los TARC. Este precepto en sus apartados 1 y 3 dice así:

«1. Las resoluciones que pongan fin al procedimiento de recurso se ejecutarán por el órgano de contratación autor del acto impugnado con sujeción estricta a sus términos.

Si la resolución acordara la anulación del procedimiento de licitación, para poder proceder a la adjudicación del contrato, el órgano de contratación deberá convocar una nueva licitación. Cuando proceda la retroacción del procedimiento, la anulación de trámites ordenada por el Tribunal no será obstáculo para que se mantenga la validez de aquellos actos y trámites cuyo contenido hubiera permanecido igual de no haberse cometido la infracción.

3. Los incidentes que planteen los interesados en relación con la ejecución de la resolución, se resolverán por el Tribunal previa audiencia de los interesados.

A tal fin, recibido el escrito planteando el incidente, el Tribunal dará traslado del mismo, con la documentación que lo acompañe, a los interesados a fin de que, durante el plazo de diez días hábiles, puedan alegar cuanto estimen oportuno.

Evacuado el trámite anterior o, en su caso, transcurrido el plazo para ello, el Tribunal resolverá el incidente en el plazo de cinco días hábiles».

Nada de ello se ha incorporado a la LCSP, salvo la frase tan genérica del art. 57.4 antes transcrita. Además este precepto no fija un plazo de comunicación del cumplimiento. Y tampoco señala cuál debe ser la actuación de los TARC en caso de que no se produzca dicha comunicación y sin embargo el recurrente comunique que el órgano de contratación no ha cumplido con la resolución delTARC. 
El problema es que la LCSP no ha dotado a los TARC de poderes de ejecución sobre sus resoluciones. Estos tendrán que valerse de lo dispuesto en el art. 36 del Real Decreto 814/2015 con la poca definición que este precepto otorga a los incidentes de ejecución, puesto que no los desarrolla $y$, además, tienen un simple rango reglamentario.

En cualquier caso, la conducta de un órgano de contratación que no ejecutara una resolución de unTARC y se mantuviera en su decisión anterior, constituye, a mi entender, un claro ejemplo del delito de prevaricación, que el TARC o el propio recurrente podrían poner en conocimiento del Ministerio Fiscal.

Por otra parte, las resoluciones de los TARC constituyen actos firmes y respecto de ellas podría instarse la modalidad de recurso contencioso-administrativo contra la inactividad de la Administración que no ejecuta un acto firme.

\section{Conclusiones}

La LCSP ha introducido importantes novedades en relación con los TARC y sus poderes. Ciertamente no ha modificado su actual configuración en sus rasgos esenciales, aunque sí las características de su objeto y de las actuaciones impugnables. Así el número de recursos especiales se acrecentará por el simple hecho de la enorme rebaja en su cuantía que ahora no se halla sujeta a los umbrales comunitarios y a sus cambios (44). Por otra parte, se acrecienta asimismo el número de actuaciones impugnables con la extensión, principalmente, a las modificaciones contractuales y a los encargos.

De manera más débil se han incrementado los poderes de los TARC que quedan cada día más lejos de los propios de un recurso administrativo (aunque el recurso especial así lo sea) y se acercan algo más a una vía "cuasijudicial» previa. Se han apuntado algunas cuestiones como dar acceso al expediente, resolver sobre la confidencialidad, ser informados de la ejecución de sus resoluciones e imponer multas a los recurrentes por importes más significativos (hasta 30.000 euros). Con todo, algunos aspectos deben aplicarse en la práctica de un modo nuevo: por ejemplo, el recurso especial no se debe limitar a ser sólo revisor, sino que debe incidir - cuando así proceda - en la determinación de la situación jurídica individualizada; y también debe convertirse en vía adecuada para la concesión de indemnización por daños y perjui-

(44) Así por ejemplo la modificación de umbrales de contratos sujetos a regulación armonizada que ha entrado en vigor el 1 de enero de 2018 y que supone una elevación de sus cuantías, para nada afecta al recurso especial. 
cios, tal como está prevista en la Directiva de recursos desde su momento inicial en 1989.

Los TARC cuentan con tres enormes ventajas sobre la vía judicial:

1) La rapidez de su enjuiciamiento, con un máximo de dos meses.

2) La efectividad de sus resoluciones que son directamente ejecutivas, sin que la interposición de un recurso contencioso-administrativo paralice por sí mismo su ejecución.

3) La especialización de sus miembros en el Derecho administrativo sobre la contratación pública.

Siendo ciertas estas tres ventajas, el recurso especial debe tender a una profundización de los poderes de los TARC que les convierta en una justicia administrativa amplia y eficaz.

El éxito de los TARC en el futuro, con todo el potencial que les brinda la LCSP, se cifra en estos aspectos:

1) Que los TARC de ámbito autonómico o local se configuren (o mantengan allí donde ya existan) mediante un modelo de órgano colegiado con similares requisitos a los establecidos para el TACRC, que garanticen su preparación e independencia. Esto corresponde, principalmente, a las Comunidades Autónomas y también a las entidades locales que, conforme a lo previsto en la LCSP, opten por la creación de un órgano especializado propio. No se deben crear Tribunales Administrativos de segunda división, puesto que ello supone una vulneración de la Directiva 89/665/CEE.

2) Que su funcionamiento sea ágil y eficaz, bajo los parámetros de rapidez y efectividad a que nos han venido acostumbrando. Sólo si los TARC continúan dictando sus resoluciones en los breves plazos de tiempo y con la calidad con que lo están haciendo (basta ver sus memorias y resoluciones), tendrán éxito y cumplirán lo dispuesto en la Directiva 89/665/CEE.

3) Que actúen como auténticos Tribunales (aunque no sean jurisdiccionales) de la contratación pública, con los poderes propios o muy similares a los de los órganos jurisdiccionales, de modo que la justicia que impartan sea plena y efectiva.

\section{Bibliografía sucinta}

Existen un gran número de estudios sobre el recurso especial en materia de contratación pública. Sin embargo, aquí me voy a limitar a citar los más recientes $y$, en especial, aquellos que hacen directa referencia a las cuestiones tratadas en ese trabajo. 
BERENGUER AMAT, A., "El recurso especial en materia de contratación, como instrumento de control eficaz para combatir la corrupción. Cuestiones controvertidas", en Revista Jurídica de Cataluña, núm. 1/2017, págs. 69-90.

BERNAL BLEY, M. A., "Hacia la unidad del Sistema de recursos en material de contratación pública", en la obra colectiva Las vías administrativas de recurso a debate. Actas del XI Congreso de la Asociación Española de Profesores de Derecho Administrativo. Zaragoza, 5 y 6 de febrero de 2016, Ed. INAP, Madrid, 2016, págs. 489-498.

CANDELA TALAVERO, J. E., El Recurso Especial como Instrumento de Control en Materia de Contratación Pública, Ed. Fundación de Asesores Locales, Málaga, 2015.

CIERCO SEIRA, C., "Las costas procesales y el derecho de acceso a la justicia administrativa», en AGUDO GONZÁLEZ, A., Control Administrativo y Justicia Administrativa, Ed. INAP, Madrid, 2016, págs. 103149.

DOMÍNGUEZ MARTÍN, M. «El sistema de justicia administrativa y la incidencia de los mecanismos administrativos de control en la jurisdicción contencioso-administrativa: reformas y necesidades", en AGUDO GONZÁlEZ, A., Control Administrativo y Justicia Administrativa, Ed. INAP, Madrid, 2016, págs. 81-101.

FERNÁNDEZ-LOMANA, GARCÍA, M., "La suspensión cautelar de las resoluciones del Tribunal Administrativo Central de Recursos Contractuales", en Actualidad Administrativa núm. 6/2016.

GALLEGO CÓRCOLES, I., "Suspensión cautelar de las resoluciones de los Tribunales Administrativos de Recursos Contractuales", en Contratación Administrativa Práctica núm. 136/2015.

GIMENO FELIÚ, J. M., "Los tribunales administrativos especiales de contratación pública ante las previsiones del informe de la Comisión para la reforma de las administraciones públicas: balance y perspectivas", en Revista catalana de dret public, núm. 47/2013, págs. 87-102.

GIMENO FELIÚ, J. M., Sistema de Control de la Contratación Pública en España, Ed.Thomson Reuters-Aranzadi, Cizur Menor (Navarra), 2016.

GONZÁLEZ-DELEITO DOMÍNGUEZ, N., "La organización, ¿el caballo de Troya de la independencia de los tribunales administrativos de contratación?", en Actualidad Administrativa núm. 3/2017, págs. 1-14.

HERNAÉZ SALGUERO, E., "El recurso administrativo especial en materia de contratación a la luz de las resoluciones dictadas por el Tribunal Administrativo de Contratación Pública de la Comunidad de Madrid", en Asamblea. Revista parlamentaria de la Asamblea de Madrid núm. 29/2013, págs. 163-208.

HERNÁNDEZ GONZÁLEZ, F. L., "Sobre la controvertida naturaleza «jurisdiccional» de los tribunales administrativos de recursos contractua- 
les", en la obra colectiva Las vías administrativas de recurso a debate. Actas del XI Congreso de la Asociación Española de Profesores de Derecho Administrativo. Zaragoza, 5 y 6 de febrero de 2016, Ed. INAP, Madrid, págs. 499-510.

LÓPEZ MENUDO, F., «Transposición irregular de la normativa europea sobre el Tribunal de recursos contractuales: ¿Un modelo para la resolución de los recursos administrativos en general?", en la obra colectiva Derecho administrativo e integración europea: estudios en homenaje al profesor José Luis Martínez López-Muñiz, tomo 2, Ed. Reus, Madrid, 2017, págs. 1411-1434.

MALARET GARCÍA, E., "Hacia un modelo de justicia administrativa dual. Tribunales administrativos y jurisdicción contencioso-administrativa. Justicia Administrativa. Instituciones Administrativas e instancias jurisdiccionales. Una perspectiva necesariamente de conjunto del control de la actividad administrativa», en AGUDO GONZÁLEZ, A., Control Administrativo y Justicia Administrativa, Ed. INAP, Madrid, 2016, págs. 43-78.

MARTÍN VALERO, A. I., "Especialidades procesales en los recursos frente a las resoluciones de los Tribunales de Recursos Contractuales", en Actualidad Administrativa núm. 12/2017.

MOREU CARBONELL, E., "Valoración del sistema español de recursos administrativos: conclusiones", en la obra colectiva Las vías administrativas de recurso a debate. Actas del XI Congreso de la Asociación Española de Profesores de Derecho Administrativo. Zaragoza, 5 y 6 de febrero de 2016, Ed. INAP, Madrid, 2016, págs. 827-838.

RAZQUIN LIZARRAGA, J.A., "El sistema especial de recursos en la contratación pública tras la reforma de la Ley de Contratos del Sector Público", en Revista General de Derecho Administrativo núm. 25/2010.

RAZQUIN LIZARRAGA, M. M., "Los Tribunales y Consejos Administrativos sobre recursos y reclamaciones", en PAREJO ALFONSO, L. Y VIDA FERNÁNDEZ, J. (Coord.), Los retos del Estado y la Administración en el siglo XXI. Libro Homenaje al profesor Tomás de la QuadraSalcedo Fernández del Castillo, ed. Tirant lo Blanch, Valencia 2017, t. I, págs. 549-571.

SANTAMARÍA PASTOR, J. A., "El sistema de Tribunales Administrativos de recursos contractuales", en Asamblea. Revista parlamentaria de la Asamblea de Madrid núm. 32/2015, págs. 41-77.

SANTAMARÍA PASTOR, J. A., Los recursos especiales en materia de contratos del sector público, Ed. Aranzadi, Cizur Menor (Navarra), 2015.

SANTIAGO FERNÁNDEZ, M. J., "Los tribunales administrativos de recursos contractuales como mecanismos de control en la contratación pública. Perspectiva actual y de futuro», en Auditoría Pública núm. 66/2015, págs. 105-118. 
VALCÁRCEL FERNÁNDEZ, P., «El recurso especial en materia de contratos públicos: en la senda del derecho a una buena administración", en la obra colectiva Las vías administrativas de recurso a debate. Actas del XI Congreso de la Asociación Española de Profesores de Derecho Administrativo. Zaragoza, 5 y 6 de febrero de 2016, Ed. INAP, Madrid, 2016, págs. 303-367.

Trabajo recibido el 15 de enero de 2018

Aceptado por el Consejo de Redacción el 16 de febrero de 2018 
LABURPENA: Kontratuen inguruko Errekurtsoei buruzko Auzitegi Administratiboei buruzkoa da lan hau. Organo horiek ez dira judizialak, eta kontratu publikoen arloan egiten diren errekurtsoen ardura daukate. Errekurtsoen inguruko zuzentarau erkideak betetzeko sortu ziren, eta maila estatalean, autonomikoan eta tokikoan sortzen joan dira 2010etik aurrera. Sektore Publikoko Kontratuei buruzko 2017ko Lege berriak nabarmen zabaldu ditu organo horien eskumenak, eta modu esklusiboan ezagutzen duten errekurtso bereziari eragiten dioten aldaketak sartu ditu. Auzitegi Administratibo horien ahalak zeintzuk diren aztertzen da lanean, organo judizial baten ahalekin alderatuz horiek. Eta, administrazio-errekurtso bati dagokiona baino, aurretiko bide erdi-judiziala dela ondorioztatzen da.

GAKO HITZAK: Kontratuen inguruko Errekurtsoei buruzko Auzitegi Administratiboak. Errekurtso berezia. Kontratu publikoak.

RESUMEN: El presente trabajo versa sobre los Tribunales Administrativos de Recursos Contractuales, órganos no judiciales responsables de los recursos en materia de contratos públicos. Su creación se realizó en aras al cumplimiento de las Directivas comunitarias de recursos y se han ido instalando a nivel estatal, autonómico y local a partir del año 2010. La nueva Ley de Contratos del Sector Público de 2017 ha ampliado notablemente sus competencias y ha introducido algunas modificaciones que afectan al recurso especial del que conocen de forma exclusiva. El trabajo se centra en analizar cuáles son los poderes de estos Tribunales Administrativos, y lo hace desde su comparación con los poderes de un órgano judicial. Y llega a la conclusión de que se trata de una vía cuasijudicial previa más que la propia de un recurso administrativo.

PALABRAS CLAVE: Tribunales Administrativos de Recursos Contractuales. Recurso especial. Contratos públicos.

ABSTRACT: This paper deals about the Administrative Courts of Contractual Review Procedures, bodies not judicial responsible for review procedures. Its creation was carried out in compliance with the Community Directives on Review Procedures and has been installed at the state, regional and local level since 2010. The new Act on Public Contracts of 2017 has significantly expanded its competences and introduced some modifications that affect the special review of which they know exclusively. The paper focuses on analyzing what are the powers of these Administrative Courts, and does a comparison with the powers of a judicial body. And it concludes that these Administrative Courts are a prior quasijudicial route rather than an administrative appeal.

KEYWORDS: Administrative Courts of Contractual Resources. Special remedies. Public contracts. 